\title{
A revision of American Bennini (Hemiptera: Fulgoroidea: Cixiidae)
}

\author{
Norman D. Penny $\left.{ }^{*}\right)$
}

\begin{abstract}
The two previously known species of American Bennini are redescribed, and one new genus and species is described. Notes are given on ecology and geographical and temporal distribution.
\end{abstract}

\section{INTRODUCTION}

The tribe Bennini was erected by Metcalf (1938) to include all genera of Cixiidae with lateral processes on the fourth and fifth abdominal segments. Presently, the only known genus of this tribe found in continental America is Bennarella. Bennarella was described by Muir in 1930 to include the new species $B$. bicoloripennis and B. fusca. No subsequent information has been published on this genus. This revision was undertaken to provide more information on morphology and ecology of known species, and describe a new genus and species.

This tribe of Cixiidae superficially resembles the small Fulgorid family Achilixiidae in the tectiform wings and lateral abdominal processes, but Achilixiidae can be separated by the lack of median ocellus, deeply notched compound eyes, open clavus, position and form of the lateral abdominal processes and form of the male genitalia. Additionally, in Bennini each sensory pit of the lateral $a b$. dominal processes possesses a T-shaped seta (Fig. 5) .

\section{KEY TO GENERA OF AMERICAN BENNINI}

1a. Vertex not separated from frons by a transverse carina; lateral carinae of clypeus much higher than median carina; tegmen nervature entering anal margin at nearly right angles; first cell of cubitus (cul) approximately 10 times as long as wide .............. Amazobenna n.g. 1b. Vertex separated from frons by a transverse carina; lateral carinae of clypeus subequal in height to median carina; tegmen nervature entering anal margin at acute angle; first cell of cubitus (cul) nearly triangular, only twice as long as wide ............... Bennarella Muir

\section{Genus Bennarelia Muir}

Bennarella Muir, 1930: 12, figs. 1-3. Type-species, Bennarella bicoloripennis (orig. des.); Metcalf, 1936: 21 (cat.); 1938: 283.

HEAD - Frons and clypeus concave with elevated lateral carinae; approximately one dorsal eye dameter in width at apex, widening to 1 and $1 / 2$ dorsal eye diameters on clypeus. Vertex narrow, approximately three times wider than long. Clypeus with lower median and lateral carinae subequal in height. Median ocellus at base of frons; lateral ocelli directly in front of compound eyes and above antennal bases. Compound eyes with slight emargi. nation at anterio-ventral margin. Antennae consisting of very short scape; pedicel about twice as long as wide; and very thin flagellum about 2 and $1 / 2$ times length of pedicel.

THORAX - Pronotum much wider than long with three indistinct dorsal carinae and wide lateral lobes below compound eyes. Mesonotum with three indistinct carinae. Metepimeron with caudoventrally projecting, pointed spur.

LEGS - Covered with white powder; devoid of spines on prothoracic and mesothoracic segments.

TEGMEN - Steeply tectiform. R fourbranched. $\mathrm{M}_{1}+2$ branched; $\mathrm{M}_{3}+4$ unbranched. CuA not strongly arched at apex; CuP nearly straight. Veins entering anal margin at acute angles. Cell cul nearly triangular, twice as long as wide. Clavus closed.

(") - Instituto Nacional de Pesquisas da Amazônia, Manaus. 


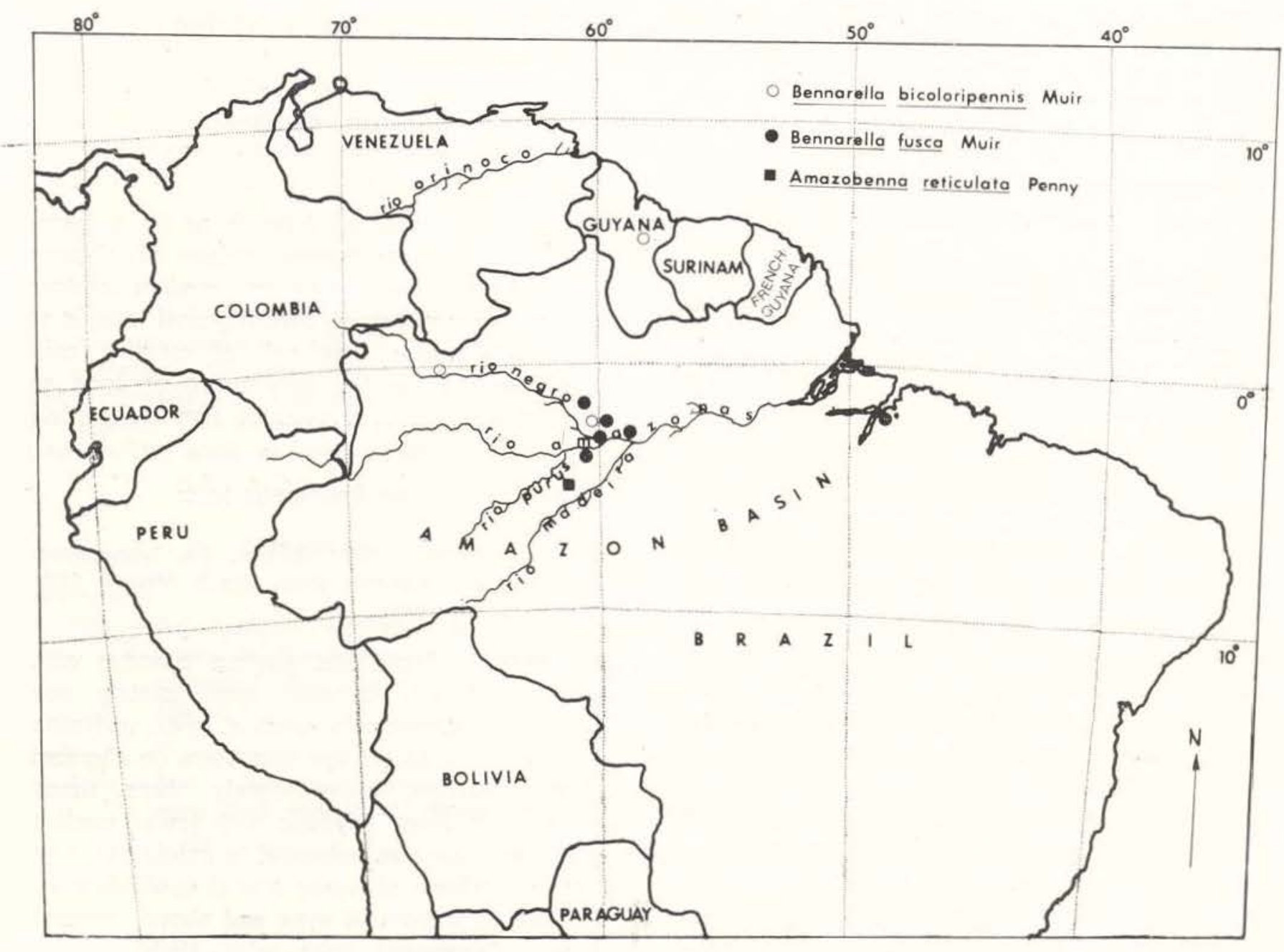

Map. 1 -- Distribution of American Bennini.

ABDOMEN - Segments four and five with large lateral processes. Process of segment 4 trumpet-shaped, with three sensory pits at the apex. Process of segment 5 trumpet-shaped. with two apical sensory pits. Segments six and seven also showing rudiments of lateral processes. Base of female ovipositor evenly curved.

KEY TO SPECIES OF BENNARELLA

1a. Apex of tegmen translucent white ....... .............. bicoloripennis Muir

1b. Apex of tegmen dark fuscous $\ldots \ldots \ldots$. ............... B. fusca Muir

\section{Bennarella bicoloripennis Muir} (Figs. 3,6)

Bennarella bicoloripennis Muir, 1930: 12. Type-tocality, Guyana, Tumatumari; Metcalf, 1936: 21 (cat.). Four male, five female syntypes deposited in the Bishop Museum, Honolulu, Hawaii, U.S.A.

Present description based on original description and two remales, pinned, with abdomens cleared in $\mathrm{KOH}$ and mounted on microscope slides.

HEAD - Covered by white powder. Dorsal part of frons and lateral carinae white; color changing abruptly to dark fuscous at level of lateral ocelli. Ventral part of frons, genae and base of clypeus dark fuscous (fig. 3), color changing abruptly to white on mid-clypeus. 
Rostrum white basally, changing to dark fuscous distally. Antennal scape and pedicel creamy white; about as long as one eye diameter.

THORAX - Pronotum dark with medial and lateral carinae white; expanded below eye as a broad, white, triangular lobe. Mesonotum dark fuscous with three longitudinal, white carinae.

LEGS - Covered with white powder. White with dark band at apex of femur. Pro- and mesothoracic tibiae without spines.

TEGMEN - Dark fuscous basally to tip of clavus (fig. 6). Tegmen apex translucent white. except for one fuscous band marked diagonally from clavus to costal margin. Claval suture and longitudinal veins of basal area white to stramineous. Wing light fuscous basally, milky white apically.

ABDOMEN OF MALE - (after Muir, 1930) Pygofer small, ventrally curved. Anal segment with ventro-basal lobe and long, narrow centrocaudal projection. Aedeagus elaborately forked, with recurved dorsal projection. Genital styles each with apically acute point.

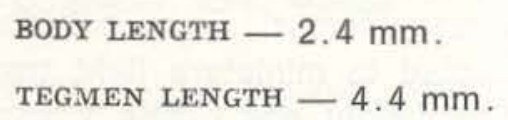

GEOGRAPHIC DISTRIBUTION - The types of this species were collected at Tumatumari, Guyana (Map 1). There are two additional females in the Systematic Entomology Collections of INPA, Manaus, from BRAzIL: Amazcnas, Reserva Ducke ( $26 \mathrm{~km}$ north of Manaus), N.D. Penny; and Amazonas, $50 \mathrm{~km}$. SE of São Gabriel de Cachoeira, N. D. Penny.

TEMPORAL DISTRIBUTION - This species has been collected in the northern part of the Amazon Basin on 20 January and centrai part of the Amazon Basin on 12 January. The Guyana types were collected on 19 July, suggesting possible seasonal disjunction between northern and southern populations, or possibly year-round emergence, as with the other known species of this genus.

ECOLOGY - This species has been collected in very moist, terra firme, primary forest situations. Collections were made of individuals resting on leaves of understory shrubs.

\section{Bennarella fusca Muir \\ (Figs. 2, 4, 5, 7)}

Bennarella fusca Muir, 1930: 13. Type-locality, Brazil. Pará, Belém; Metcalf, 1936: 21. Holotype male in the Bishop Museum, Honolulu, Hawaii, U.S.A. Present description based on 7 males, 11 females, pinned.

HEAD - Covered with whitish powder. Dark fuscous (fig. 2), except for area of

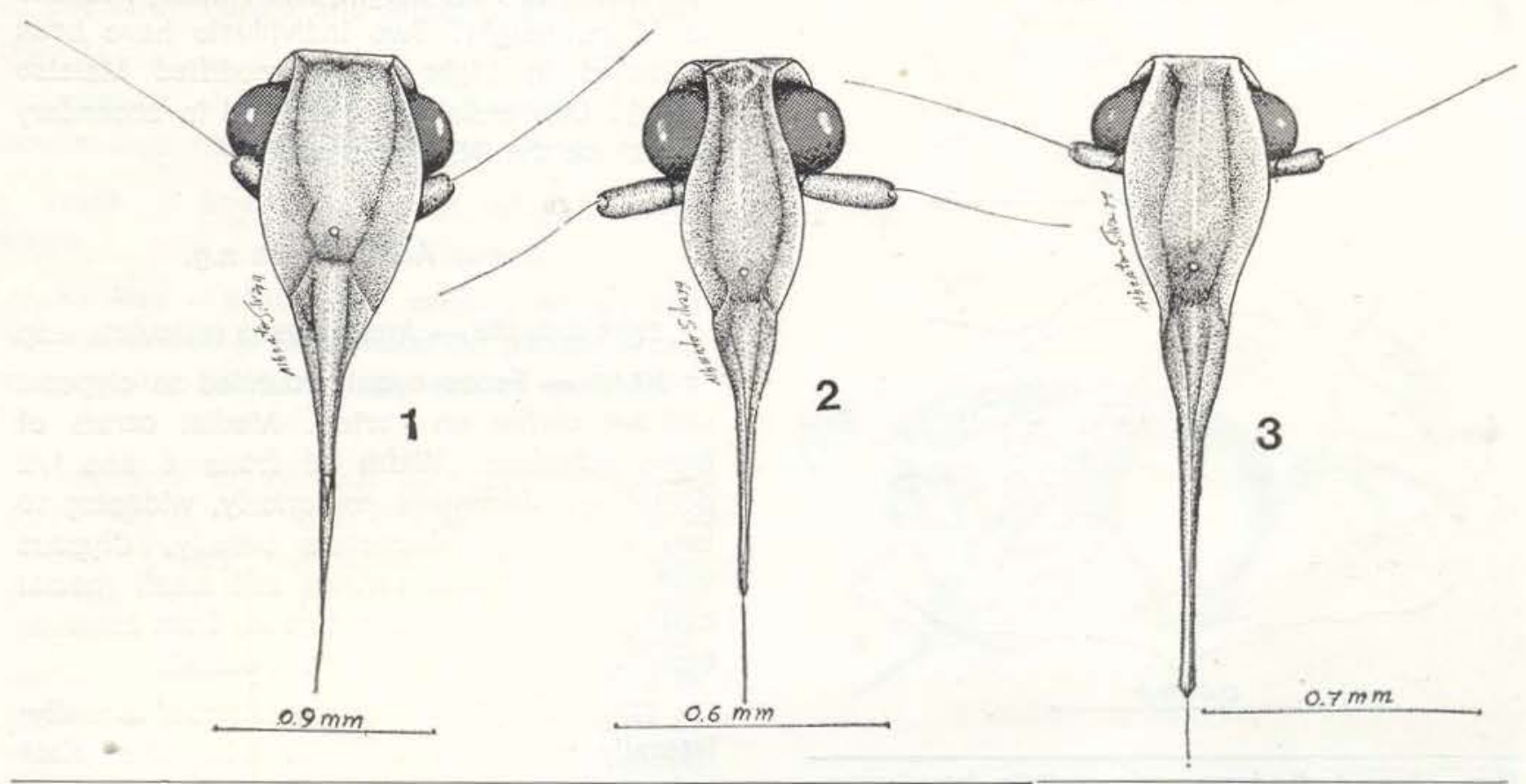

Figs. 1-3-1 A. reticulata, frontal view; 2 B. fus ca, frontal view; 3 B. bicoloripennis, frontal view. 
lateral carinae above compound eyes creamy white. Antennal scape and pedicel slightly larger than diameter of eye.

THORAX - Dark fuscous throughout pronotum and mesonotum.

LEGS - Covered with whitish powder. Forelegs and mesothoracic legs dark fuscous throughout. Metathoracic legs stramineous with dark apical band on femur. Prothoracic and mesothoracic tibiae devoid of spines.

TEGMEN - Fuscous throughout, except for clear amber, longitudinal bands in area of claval suture and base of $M$, and clear amber spots about half distance to terminal apex on both costal and anal margins (fig. 7).

ABDOMEN OF MALE - Anal segment 10 forming a cup-shaped dorsal plate over aedeagus. Anal segment 11 small, membranous to lightly sclerotized, oblong. Aedeagus con-
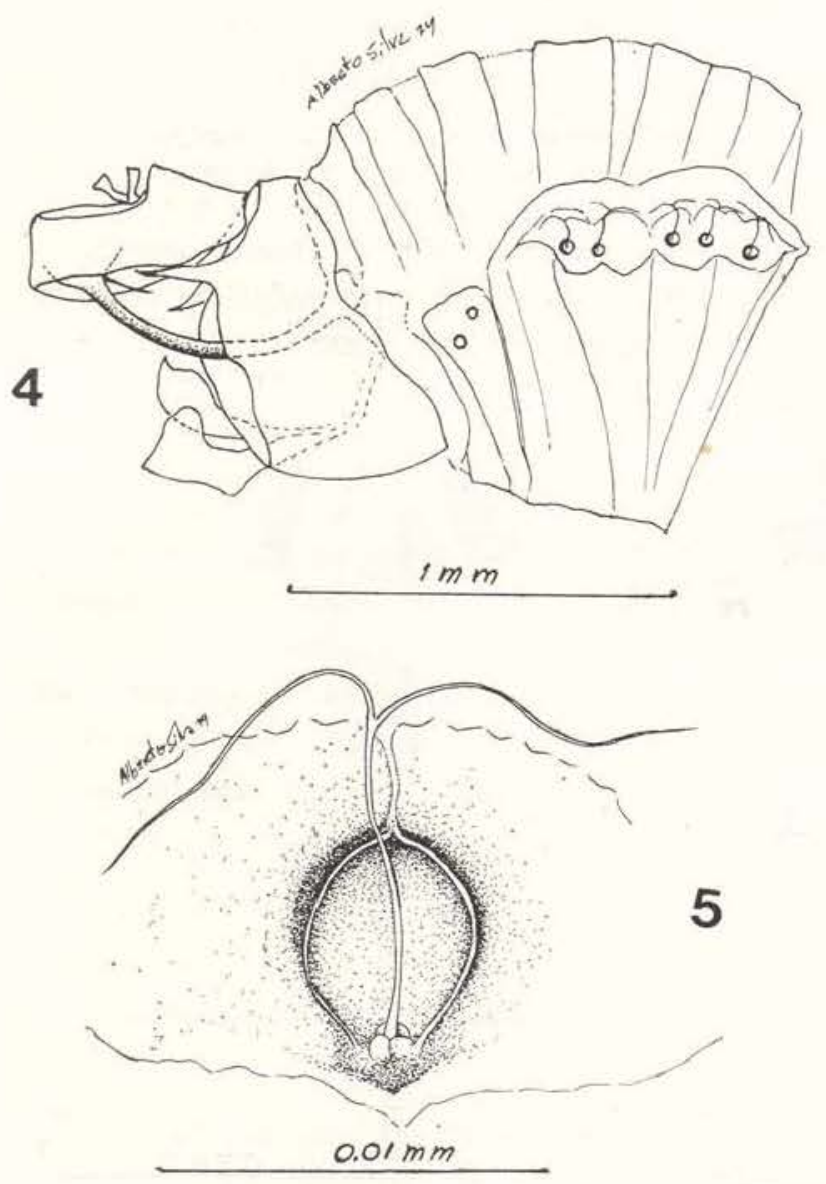

Figs. $4-5-4$ B. fusca, male genitalia, lateral view; 5 B. fusca, sensory pit of lateral abdominal process. sisting of heavily-sclerotized dorsal and ventral projections. Genital styles truncate distally, with dorsal lobes; connected anteriorly with aedeagus (fig. 4) .

BODY LENGTH -2.0 to $2.4 \mathrm{~mm}$. $(2.4 \mathrm{~mm}$. in holotype) .

TEGMEN LENGTH -3.5 to $4.0 \mathrm{~mm}(4.0 \mathrm{~mm}$. in holotype).

GEOGRAPHIC DISTRIBUTION - This species was originally collected from Belém, Pará, BRAZIL (Map. 1). Further specimens in the Systematic Entomology Collections of INPA, Manaus, are from BRAzIL: Amazonas, ReservDucke (26 km. north of Manaus), J. R. Arias; Amazonas, Reserva Campinas ( $45 \mathrm{~km}$. north of Manaus), N. D. Penny; Amazonas, Manaus, J. R. Arias: Amazonas, $219 \mathrm{~km}$. east of Manaus on AM-010, N. D. Penny; Amazonas, $52 \mathrm{~km}$. SW of Manaus on BR-319, E. Castellon.

TEMPORAL DISTRIBUTION - This species has been collected in the central Amazon Basır: during most months of the year, but appears to be most abundant from January to March.

ECOLOGY - A large number of individuals were noted in the central Amazon Basin to be resting on upright, dead tree trunks in moist. terra firme, primary forest. Four individuals have been attracted to miniature light traps: two males at $1 \mathrm{~m}$. height, and $1 \mathrm{male}, 1$ female at $15 \mathrm{~m}$. height. Two individuals have been collected in flight traps (modified Malaise traps). One male was collected in secondary growth on the INPA campus.

\section{Genus Amazobenna n.g.}

TYPE SPECIES - Amazobenna reticulata n.sp.

HEAD - Frons evenly rounded to clypeus, without carina on vertex. Medial carina of frons indistinct. Width of frons 1 and $1 / 2$ dorsal eye diameters posteriorly, widening to two dorsal eye diameters basally. Clypeus with foliate lateral carinae and small medial carina. Eye entire and separated from antenna! base by half the diameter of pedicel.

THORAX - Pronotum very narrow dorsally: laterally expanded to form triangular plate below eye. Carinae of mesonotum indistinct. becoming obsolete posteriorly. 
LEGS - Prothoracic and mesothoracic legs devoid of spines. Second tarsal segment with a row of small spines.

TEGMEN - Steepiy tectiform. R fourbranched. $\mathrm{M}_{1}+2$ branched; $\mathrm{M}_{3}+4$ unbranched. CuA srongly arched near apex, CuP nearly straight. Veins entering anal margin at nearly right angles. Cell cul quadrangular, about 10 times as long as wide.

ABDOMEN - Lateral processes of fourth and fifth abdominal segments trumpet-shaped, with three and two sensory pits, respectively. Vestiges of processes on sixth abdominal segment. Base of female ovipositor lobate.

ETYMOLOGY - This new generic name, Amazobenna, refers to the area where the original specimen was collected, and Benna, the type genus of the tribe.

\section{Amazobenna reticulata n.sp.}

(Figs. 1, 8)

Description based on 1 female, pinned, with abdomen cleared in $10 \% \mathrm{KOH}$ and mounted on microscope slide. Holotype female deposited in the Systematic Entomology Collections, INPA, Manaus.

HEAD - Dark fuscous, with lighter fuscous at posterior margin and along lateral carinae (fig. 1).

THORAX - Pronotum light fuscous. Mesonotum dark fuscous. Scutellum stramineous.

LEGS - Stramineous with infuscate markings.

TEGMEN - Base color creamy white with fuscous markings in a reticulate pattern along many veins. CuA strongly arched near apex (fig. 8) .

ABDOMEN OF FEMALE - Dorsal segments dark fuscous anteriorly and pale yellow posteriorly. Lateral processes of segments four and five light fuscous to pale yellow. Latera! process of segment 4 bearing three apical, heavily sclerotized pits; each pit with a T. shaped seta. Process of segment 5 equal in size to process of segment 4 , bearing 2 apical, heavily sclerotized pits. Process of segment 6 smaller in size and bearing two apical, heavily sclerotized sensory pits. Base of process of segment 4 with field of conical sensillae and processes basally bearing several long setae.

$$
\text { BODY LENGTH }-4.5 \mathrm{~mm} \text {. }
$$

TEGMEN LENGTH $-7.0 \mathrm{~mm}$.

GEOGRAPHIC DISTRIBUTION - BRAZIL: Amazonas, $275 \mathrm{~km}$. SW of Manaus on BR-319, N. D. Penny.
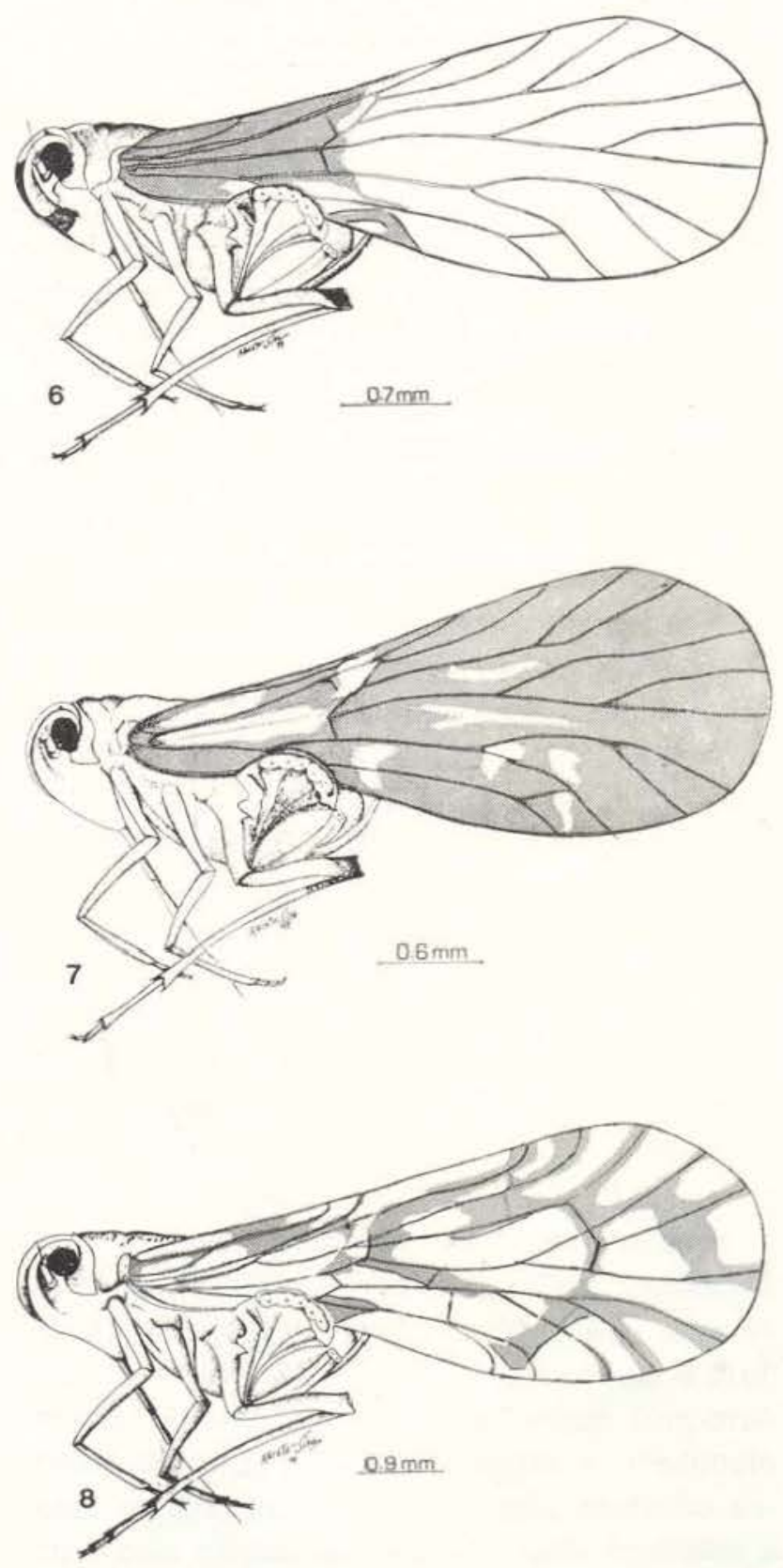

Figs. $6-8-6$ B. bicoloripennis, lateral view; 7 B. fusca, lateral view; 8 A, reticulata, lateral view. 
TEMPORAL DISTRIBUTION - The only known specimen was collected on 17 May.

ECOLOGY - The type female was collected while resting on a leaf of an understory shrub of a moist, terra firme, primary forest.

ETYMOLOGY - This species is named for the reticulate pattern of the tegmen.

\section{ACKNOWLEDGMENTS}

I wish to thank Sr. Alberto Coelho da Silva for the distribution map and drawings. Dr. Lois O'Brien is to be thanked for the initial identifications of the two species of Bennarella and for reviewing an early draft of the manuscript. Finally, I wish to thank Dr. Jorge R. Arias for his logistical support.

\section{Resumo}

As duas espécies de Bennini Americana previamente conhecidas são redescritas. Um novo gênero é estabelecido sendo descrita e colocada nela uma nova espécie. Notas ecológicas, distribucionais e temporais são dadas para todas três espécies neotropicais.

\section{LITERATURE}

METCALF, Z.F.

1936 - General Catalogue of the Hemiptera. Fasc. 4 (2). Fulgoroidea, Cixiidae: 1-269, Mass.

1938 - The Fulgorina of Barro Colorado and other parts of Panama. Bull. Mus. Comp. Zool., Harvard University., 82: 277-423; pls.

MUIR, F.

1930 - Three new species of American Cixiidae (Fulgoroidea Homoptera). Pan-Pacific Ent., 7: 12-14; figs. $1-4$.

(Aceito para publicação em 25/06/79) 